\title{
The Role of Roudlotur Ridwan Islamic Boarding School in Empowerment of Islamic Communities Through Life Skills in the Child Social Welfare Institution (CSWI) Program in East Lampung District
}

\author{
Khoirurroji'in ${ }^{1, *}$, MA.Achlami HS ${ }^{2}$, Jasmadi ${ }^{2}$, Fitri Yanti ${ }^{2}$, \\ Kholid Hidayatullah ${ }^{2,3}$, Muhamad Rudi Wijaya ${ }^{2,4}$, Ahmad Hadi Setiawan ${ }^{2,5}$ \\ ${ }^{1}$ Department of Syariah, IAI Agus Salim Metro, Lampung, Indonesia \\ ${ }^{2}$ Department of Dakwah, UIN Raden Intan Lampung, Indonesia. \\ ${ }^{3}$ Departmen of Syariah Economic Law, Universitas Muhammadiyah Pringsewu, \\ Lampung, Indonesia. \\ ${ }^{4}$ Department of Syariah Economic Law, STIS Darul 'Ulum Lampung Timur, \\ Lampung, Indonesia. \\ ${ }^{5}$ Department of Education, Faculty of Education Arabic, STIT Darul Fattah Lampung, Indonesia \\ *Corresponding author Email: Masri.jadidah@gmail.com, rudiwijaya68@gmail.com
}

\begin{abstract}
This research focuses on the role of the Roudhotur Ridwan Islamic boarding school in empowering the Islamic community through life skills at the Child Social Welfare Institution (CSWI) in East Lampung Regency. This research is qualitative research; qualitative research is a research procedure with the results of descriptive data in the form of written words, spoken words, or observable human behavior. Data collection is got by interview, documentation, observation. The informants or resource persons are which consist of caregivers, instructors, village chiefs of Islamic boarding school, students, parents of students and CSWI administrators and existing stakeholders. The results showed the implementation of the community empowerment model, namely: First: The process of empowerment through life skills in the Islamic boarding school Roudlotur Ridwan in the CSWI program there are three processes: 1. Awareness stage: a. Building Mental Spirituality through Ruhul Jihad b. Leadership and Entrepreneurship 2. Capacity Building: Training through Life Skills 3. Powering. Second: Results of the Empowerment Process through Life Skills at the Roudlotur Ridwan Islamic Boarding School in the CSWI Program a. Output Empowerment: Character Strengthening, Economic Strengthening, Strengthening Emotional Ties, Strengthening institutions b. Outcome Empowerment; The economic empowerment of CSWI children is shown by the formation of skilled human resources with good character and honest and trustworthy entrepreneurs who are based on strong religious practice, as well as the realization of children's independence and welfare which is marked by economic strengthening.
\end{abstract}

Keywords: Roudlotur Ridwan Islamic, Boarding School, Child Social Welfare Institution

\section{INTRODUCTION}

Islamic boarding school as a da'wah institution constantly provides interesting treats to be studied from various perspectives. Is it related in the fields of economy, [1] social capital, [2] management, [3] and so on. The interest in studying Islamic boarding school is a familiar thing because Islamic boarding school always displays new phenomena along with the natural and even mechanistic development of the Islamic boarding school, of course starting from the Islamization of the archipelago.

As a da'wah institution, Islamic boarding school gave birth to Muslim intellectuals from time to time. This is because various learning methods are applied, so that the Islamic boarding school now has various styles, including traditional and modern ones
[4]. Apart from this, Islamic boarding schools also carry out innovations that are directed at improving the quality of life of their students, not only in the field of religion, but also preparing their students to respond to the challenges of the times, where students must fill strategic positions, besides Islamic boarding school graduates are expected to be a driving force for welfare of the social environment.

The condition of helplessness experienced by the community is partly due to their inability to compete in an increasingly competitive world of work, so that CSWI has the thought of providing various skills that must be possessed by its students. These thoughts are implemented in the form of non-formal education, namely training in life skills in various fields tailored to the interests of the students. 
Life Skill training is education outside the formal education pathway that can be carried out in a structured and flexible level that lasts a lifetime and the level of competence of its students can be equalized to that of formal educators. Empowering students (neglected children or underprivileged children) is one way to equip these children to be empowered, independent in their capacity to meet their needs so that they will be less active on the streets and even neglected children do not interfere anymore, for that the development of this service can be done by providing provision through providing skills to be useful in the future.

The impact of the training above can be seen from the alumni of the Roudlotur Ridwan Islamic Boarding School CSWI who were fostered in the CSWI Roudlotur Ridwan East Lampung who have succeeded and succeeded in establishing children's independence / welfare which is marked by income and welfare, giving birth and turning their foster children into character entrepreneurs, honest, trustworthy and noble character based on a strong religious knowledge.

\section{METHOD}

In this study, researchers used a qualitative descriptive analysis. The informants of this study were the Village Government and Community, as well as other supporting sources. Data were collected through interviews, documentation, and observations.

This study used qualitative analysis as stated by Matthew B. Miles and A. Michael Huberman which divided into three stages, 1) Data reduction or selection and focus on simplifying, abstracting, and transmitting raw data from notes or records in the field, 2) Data presentation for concluding, 3) Data verification or drawing conclusions based on reduction, interpretation, and presentation of data. Analysis and data collection activities through these three stages run interactively and according to the cycle [5].

To data's test the validity, a triangulation's technique (cross-check) was conducted. The triangulation process was carried out continuously throughout data collection and data analysis until there were no differences and no need for informant confirmation. Triangulation was carried out by testing the understanding of researchers and informants [6].

\section{RESEARCH METHODOLOGY}

This research is qualitative in research; qualitative research for a research procedure with descriptive data results form of written words, spoken words, or observable human behavior. By using qualitative research, researchers can get to know and explore the subject of research personally or groups to analyze how these subjects developed their own definition of the living world they experienced [5].

\section{RESULT AND DISCUSSION}

Empowerment Process through Life Skills, the activities carried out by LKSA in order to develop creating independence, empowering students are through programs or forms of life skills and skills training, something short-term educational activities using procedures systematic and organized, so that's operational employees learn to knowledge of engineering techniques for expertise to certain objectives are called training. Training can also be understood as a short-term educational activity using systematic procedures to change employee behavior in one direction in order to improve organizational goals. Therefore, empowerment emphasizes that people acquire sufficient skills, knowledge, and power to influence their lives and the lives of others who concern them. In addition, community empowerment is a concept of economic development that encompasses and includes social values. This concept, which is people, participatory, empowering, and sustainable, reflects a new development paradigm [6].

From the two theories above, it can be seen that in this context community empowerment activities are efforts to build the strength of orphans, abandoned children themselves, by encouraging, strong motivation and raising awareness of their potential and trying to develop it.

Mustafa Kamil said that training is an act of increasing the knowledge and skills of an employee, in this case abandoned children orphans to carry out certain jobs [7]. And training according to Mengko Prawira is the process of knowledge and skills as well as an attitude of being skilled and able to carry out their responsibilities better and according to standards [8].

The empowerment process that is applied first is awareness, which is the stage where people are given enlightenment and encouragement to realize that they have the right to have the capacity and enjoy something better. Awareness efforts undertaken include:

1. Mental Spiritual Development (physical and mental guidance), For the empowerment process, awareness is the main foundation. The 
empowerment process will have no meaning at all without the emergence of awareness from the community itself because; the main element of the key to success of awareness is the motivational factor and community awareness to want to change its own future.

In the process of empowerment, the Roudlotul Ridwan Islamic boarding school in the CSWI program raised awareness to the training participants, the first time that was carried out was giving motivation, for example, to participants being conveyed that learning is part of jihad in the path of Allah SWT, given the enlightenment that every human being has the opportunity to become someone who success. Humans can change and must continue to change, there are many opportunities for success in the present and in the future that must be prepared to achieve it. Success is not only seen from the material side but also from the spiritual side. Why be successful if he does not have faith. Motivation is continuously carried out so that it is hoped that it will raise the awareness that is in them about the motivation to improve things that are better than before.

The next awareness process carried out by the Roudlotul Ridwan Islamic boarding school is mental spiritual development. Therefore, the platform built by the Roudlotul Ridwan Islamic boarding school through the CSWI program in the empowerment process is a model of empowerment Islamic boarding school.

2. Leadership and Entrepreneurship

As a provision of knowledge and experience when later they are involved in the community and have direct contact with the business world, the empowerment participants after participating in the training process are given material on leadership and entrepreneurship.

The preparations made will be closely related to how the quality of existing human resources is improved by providing various life skills and increasing entrepreneurial insight. Being an entrepreneurial entrepreneur who is educated and trained in facing challenges and being able to find business opportunities that exist is a profitable alternative for students to apply in real life. Entrepreneurship is a strong belief that exists in a person to change the world through his ideas and innovations.

3. Building Human Capacity

Building human capacity is an effort that provides expertise and skills to students who have self-awareness to change tasks as best as possible the forms of capacity building carried out by the Roudlotul Ridwan Islamic boarding school are:

a) Training on Convection Sewing Skills, b) Training for Suitable Planting Flowers, c) Training on Automotive Machinery for Motorcycles d) Training on Suitable Planting for Chili e) Training on planting fruit seeds g) Training on Making Brick h) Training on Freshwater Fish Cultivation

\subsection{The Roudlotur Ridwan Islamic Boarding School Empowerment Model in the CSWI Program through Life Skills.}

Model is a real form of program planning. More explicitly stated the manifestation of identification and in-depth analysis resulting in the form of a framework for achieving change. As usually happens in the empowerment process, when the problem is understood, then it creates the right model to answer the problem. There are times when one model cannot be applied to communities outside the study area or in all areas. When viewed from the theory of community empowerment models expressed by Usman that models of community empowerment include [9]: (1) Local community development model (Locality Development), (2) Social Planning, (3) Social Action. So in terms of the implementation of empowerment, it can be seen that the program formulated by the development of Life Skills at the Roudhotur Ridwan Islamic boarding school uses two approaches (1) social planning and local community empowerment (locality development). 


\subsection{The formulation of the Entrepreneurial Students Model of the Roudlotul Ridwan Islamic Boarding}

School in Empowering Islamic Communities through Life Skills

Namely the Elements Depicted in the Chart

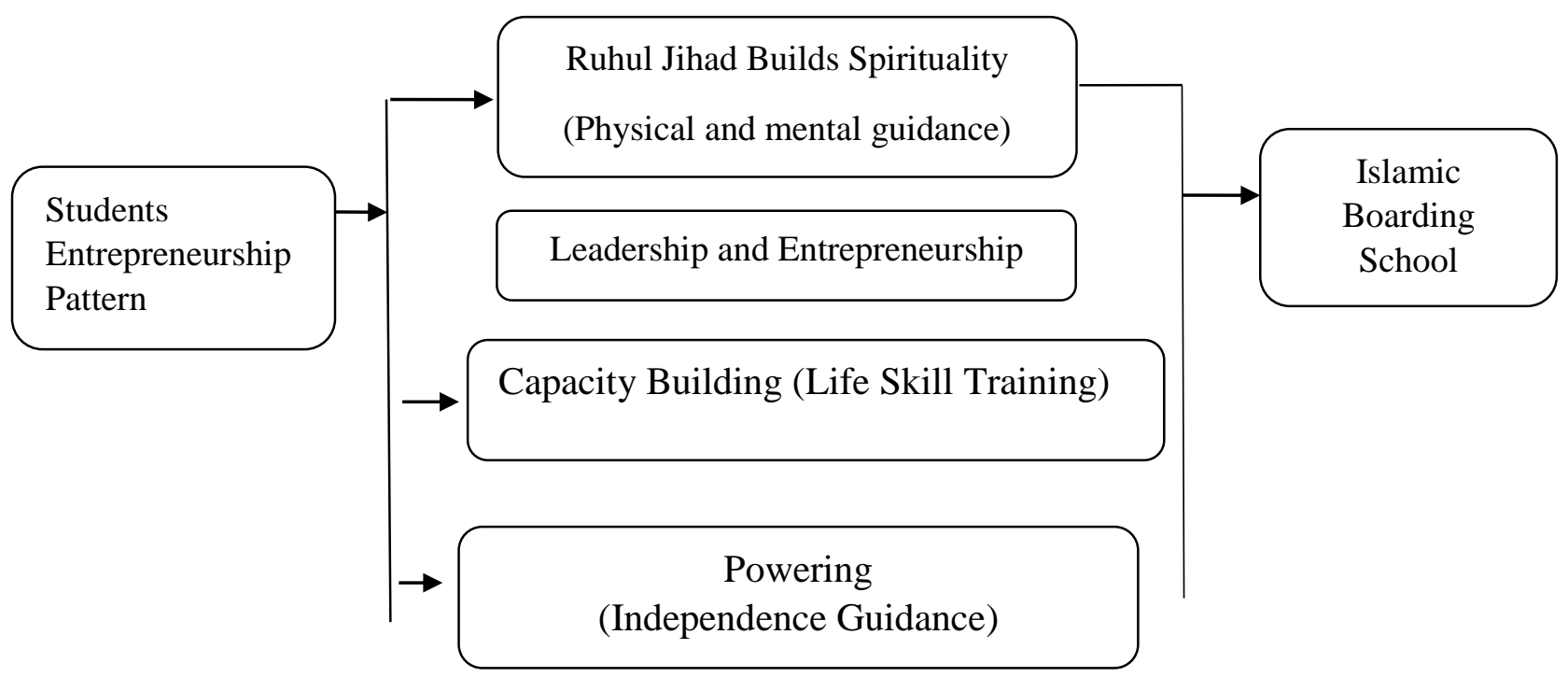

FIGURE 1. Empowerment Model of Entrepreneurial Students through Life Skills at the Roudlotur Ridwan Islamic Boarding School, East Lampung Regency

\subsection{Results of Empowerment of Roudlotur} Ridwan Islamic Boarding School through Life Skills in East Lampung Regency

a. Character strengthening

In Islamic teachings the estuary of the process of community economic empowerment is not solely for obtaining improvement, independence and prosperity but also in order to achieve good afterlife happiness

b. Economic strengthening

As explained in the previous theory, economic strengthening is an important effort in every empowerment. How empowerment that does not produce or leave a beneficial impact to improve the standard of living can increase the disappointment of the empowered community.

c. Emotional Bonds Strengthening

Strengthening emotional bonds is the result of the empowerment process in the environmental sector, an activity that is needed so that environmental damage will not interfere with the sustainability or activities and integrity of the target community where collaboration between CSWI alumni Roudlotur Ridwan in the life skill program is influenced by a strong emotional bond. From the same background, namely a family that is completely deprived, has experienced difficult life, living on the streets makes them strengthen each other. When there are those whose lives have improved, they will help others to build their careers after graduating from the training program.

d. Institutional strengthening

Institutional strengthening is the result achieved by Putri Tuan Islamic Boarding School in implementing life skills training in building networks both internally and externally. The results of institutional strengthening are marked by the formation of collaborations with other institutions.

e. Roudlotul Ridwan Islamic Boarding School Partnership with Government and Community

The partnership model carried out by the Roudlotul Ridwan Islamic boarding school in the life skill training program is a mutuality relationship, namely a relationship that provides mutual benefits and benefits to achieve common goals. 


\section{CONCLUSION}

Based for the research results and discussion, conclusions can to drawn The Process of Empowering the Roudlotur Ridwan Islamic Boarding School through Life Skills is carried out in four aspects, namely: Ruhul Jihad as Strengthening Mental Spiritual Development, Leadership and Entrepreneurship, Building human capacity, Empowering. Formulation of the Entrepreneurial students at the Roudlotur Ridwan Islamic Boarding School through Life Skills in the CSWI Program.

\section{REFERENCES}

[1] Rizal Muttaqin, Independence and Economic Empowerment Based on Islamic Boarding Schools (Study on the Role of Al-Ittifaq Islamic Boarding School, Rancabali District, Bandung Regency on the Independence of the Santri Economy and the Economic Empowerment of the Surrounding Communities), "Journal of Indonesian Sharia Economics, Volume I, No. December 2, 2011". See also Syahrul Falah dan Irham Zaki, Community Economic Empowerment by Islamic Boarding Schools in the Kelurahan Kejawan Putih Tambak Surabaya, Journal of Sharia Economics Theory and Applied Vol. 4 No. April 4, 2017.

[2] Farahdilla Kutsiyah, Agoes Kamaroellah, Ummu Kulsum, The Relationship Between Social Capital and Institutional Efficiency in the Sidogiri Islamic Boarding School Cooperative, Pasuruan, Al Masraf: Journal of Financial Institutions and Banking. Volume 4, Number 1, January-June 2019.

[3] Akbar Ibrahim, Sobar, Khambali. Management of the Dirosah Islamiyah Private Program at the Daarut Tauhiid Islamic Boarding School in Bandung, Ta'dib: Journal of Islamic Education, Vol. 7 No. 1 (2018)

[4] Ahmad Damanhuri, Endin Mujahidin, Didin Hafidhuddin. Pesantren Management Innovation in Facing Competition in the Era of Globalization, Ta'dibuna, Vol. 2, No. 1, April 2013.

[5] Miles, Huberman dan Mattew, Translation Qualitative Data Analysis. Jakarta: UIPress, 1984

[6] Burhan Bungin, Qualitative Research Data Analysis; Philosophical and Methodological Understanding Towards
Mastery of Application Models. Jakarta: PT. Raja Grafindo Persada, 2003.

[7] Aris Budiman, Research Design, Qualitative \& Quantitative Approaches, (Jakarta: KIKI Press, 2016), p. 84

[8] Edi Suhartono, Building Community Empowering People, (Bandung Revika Aditama, 2010) p. 59

[9] Aprilia Theresia, et.al. Community March Development, (Bandung Alfabeta, 2014), p. 91

[8] Mustofa kamil, pendidikan non-formal pengembangan melalui pusat kegiatan belajar mengajar (PKBM) di Indonesia (sebuah pelajaran dari komunikan Jepang), (Bandung: Alfabeta, 2010).p .3

[10] Edi Suharto, Building Communities Empowering People.: strategic study of social welfare development and social work. (Bandung: Refika Aditama, 2010), p. 43. 